\title{
Geomorphosite assessment in Montesinho Natural Park (Portugal)
}

\author{
Paulo Pereira, Diamantino Pereira, Maria Isabel Cae- \\ tano Alves, Braga
}

\section{Introduction}

The term «geomorphosite» has recently been introduced as an acronym for «geomorphological site» (PANIZZA 2001). It is understood to be a landform that has acquired a special value due to human perception or exploitation (Panizza \& Piacente 1993). This value may vary, depending on the focus: scientific, ecological cultural, aesthetic and/or economic (REYNARD 2005). According to the narrow definition of the term, a geomorphosite can be any part of the Earth's surface that is important for the knowledge of Earth, climate and life history (GRANDGIRARD 1997; REYNARD 2005).

This new field of research developed from discussions within geoconservation circles which see geodiversity as an essential issue in nature conservation and environmental management. The first references appeared in the 1960's in the United Kingdom (Watson \& SLAYMAKER 1966), but it was only in the 1980's that research was undertaken to improve the knowledge of geomorphosites (or geomorphological heritage). The majority of results published stem from the United Kingdom Italy, Switzerland and Germany.

A central focus of the field is geomorphosite assessment and management. GRANDGIRARD (1999) recommends that assessment be informed by three critical questions: What? Why? How? The «what» of assessment refers to scope in terms of area size and geomorphological environment. «Why» refers to the motivation and can be described in more detail by definition of one or more main objectives, such as protection and/or promotion of a site or compilation of an inventory. «How» refers to the choice of assessment method. This choice should take scope and objectives into consideration. Further, a holistic approach to geomorphosite assessment is argued to take geomorphosite management into account (BRILHA 2005). Thus, assessment should not only involve classification of sites, but offer suggestions for their protection, promotion and monitoring.

This article describes the approach to geomorphosite assessment developed and applied at the Montesinho Natural Park (MNP) in north-eastern Portugal (Pereira 2006). The park is, with $745 \mathrm{~km}^{2}$, one of the largest protected areas in Portugal. It is situated on the Portuguese-Spanish border. The geomorphological heritage of the MNP was assessed as part of a research project on the geological heritage of the natural parks of north-eastern Portugal.

\section{Assessment methodology}

Use was made of geomorphological knowledge of the area for information on regional setting, main landforms and processes, structural framework, climatic features, human activities, geomorphological mapping, as well as other relevant natural and cultural aspects. From this information, scientific, ecological, cultural and aesthetic characteristics of landforms were identified.

An important issue was geomorphosite scale due to its relevance for assessment accuracy. As sites can range from single places to areas or panoramic viewpoints, a single place is understood here to be a landform that can be closely observed from a single point or a restricted area. Single places are usually isolated landforms or a small group of landforms. Areas are constituted by one or more groups of landforms that can only be seen when the observer is inside the area. Panoramic viewpoints are sites from where large landforms can be perceived. They include the local point the landforms observed and can also include single points and areas.

The assessment procedure includes two main stages (inventory and quantification) and six sub-stages (Tab. 1). During the inventory, geomorphosites are selected and characterized. During quantification, importance of sites is determined by attribution of values to predetermined criteria. This evaluative process also allows comparison of sites.

\subsection{Inventory}

Identification of potential geomorphosites. One of the essential aims of the inventory stage is the selection of landforms that can be defined as geomorphosites. The identification process concentrates on a predefined range of criteria: (i) «scientific value», based on a geomorphological characterization of the area or on former scientific research; (ii) value of landform aesthetics and characteristics, in relation to sites in the same or other areas; (iii) links between landforms and cultural elements, such as archaeological features, human settlements, castles, agriculture; (iv) links between landforms and ecological issues, such as fauna and flora populations. The data collected needs to be supplemented by further data such as location, size 


\begin{tabular}{|l|l|}
\hline Stages & Sub-stages \\
\hline Inventory & $\begin{array}{l}\text { i) Identification of potential } \\
\text { geomorphosites } \\
\text { ii) Qualitative assessment of } \\
\text { potential geomorphosites } \\
\text { iii) Selection of geomorphosites } \\
\text { iv) Characterization of geo- } \\
\text { morphosites }\end{array}$ \\
\hline Quantification & $\begin{array}{l}\text { v) Numerical assessment } \\
\text { vi) Ranking }\end{array}$ \\
\hline
\end{tabular}

Tab. 1: Stages and sub-stages in geomorphosite assessment

Haupt- und Nebenphasen der Bewertung von geomorphologischen Geotopen

Etapes et sous-étapes de l'évaluation des géomorphosites

and morphology/geology and stored in the form of a database (PereIra et al. 2006).

Qualitative assessment of potential geomorphosites. After identification of sites, use is made of a qualitative evaluation process to determine intrinsic value, potential use and required protection. The intrinsic value is defined by comparison of sites against their scientific, ecological, cultural and aesthetic performance, with scores being given from nil (0) to very high (5) for each of the criteria. Potential use is defined on the basis of three main criteria: accessibility, visibility and evidence of importance in other areas (e.g. biological, archaeological). The latter aspect thus also takes current promotion and use of a site in other fields into account. Required protection includes assessment of level of deterioration and vulnerability, with scores ranging from high (3) to low (1). This aspect allows inclusion of past (deterioration) or future (vulnerability) threats in the assessment. Although the qualitative assessment may be brief, subjective and strongly influenced by the assessor's understanding of geomorphology and geoconservation, it is a fundamental step in the overall assessment. The results thereof serve as a basis for the further pre-stages in the inventory phase (Tab. 1).

Geomorphosite selection. Selection of geomorphosites is based on their rank performance during the qualitative assessment, with those sites that scored overall highest being selected for further characterisation. Potential geomorphosites with very high «scientific value» may also be selected, independent of performance in other criteria. Further, sites with high intrinsic value and high potential use (accessibility, visibility, and use of other «natural» or «cultural values») or low deterioration and vulnerability, may also be selected independently.

Geomorphosite characterization. The process involved in the compilation of the inventory is considered complete once a detailed description of each of the selected geomorphosites exists. These descriptions are expected to include cartographic data as well as information on geomorphology, «heritage value», and use and management, where applicable. The latter category would thus deal with accessibility, visibility, present uses, conservation, vulnerability, legal status and supporting infrastructures. The information collected here is expected to support the next assessment stage and is likely to be of benefit to future management initiatives.

\subsection{Quantification}

The quantification stage involves two sub-stages: numerical assessment and geomorphosite ranking. It succeeds geomorphosite characterization and builds on the data compiled during that sub-stage. The results allow comparison of the inventoried geomorphosites.

Numerical assessment. The framework for numerical assessment uses the criteria introduced in the previous stage, but divides them up into different classes in order to create two levels: principal and secondary indicators. The division of criteria took into account the possible objectives of the assessment, i.e. the protection or promotion of geomorphosites. For this reason, the principal indicator «geomorphological value» includes the secondary indicators «scientific value» (Tab. 2) and «additional values» (Tab. 3). «Management value», as second principal indicator, integrates the secondary indicators «use value» (Tab. 4) and «protection value» (Tab. 5). With regards weighting of results, «geomorphological value» and «management value» are treated the same with a maximum of 10 points each. The sum of all indicators determines the total value of the geomorphosite.

Geomorphosite ranking. The results of the numerical assessment are recorded in a quantification table. All criteria are assessed for each of the geomorphosites. As all data are recorded on the same table, a direct comparison of site ranks is possible (see example in Tab. 6). Whereas the sum of all principal and secondary indicators is expressed as total value, the sum of rank positions according to indicator (primary and secondary) are taken into account under final ranking. Consequently, the sites with lowest final ranking scores may be considered to be of greatest value in the area being assessed.

The advantage of emphasising rank averages in geomorphosite assessment is the greater attention given to overall relative value or homogeneity of criteria 


\begin{tabular}{|l|l|}
\hline \multicolumn{2}{|l|}{ F. SCIENTIFIC VALUE (ScV) (maximum 5.5) } \\
\hline Ra & Rareness in relation to the area \\
\hline 0 & It is not one of the most important 5 \\
\hline 0.25 & It is not one of the most important 3 \\
\hline 0.50 & One of the most important 3 \\
\hline 0.75 & The most important \\
\hline 1.00 & The only occurrence \\
\hline In & Integrity/Intactness \\
\hline 0 & Highly damaged as a result of human activities \\
\hline 0.25 & Damaged as a result of natural processes \\
\hline 0.50 & Damaged but preserving essential geomorphological features \\
\hline 0.75 & Slightly damaged but still maintaining the essential geomorphological features \\
\hline 1.00 & No visible damage \\
\hline Rp & Representativeness of geomorphological processes and pedagogical interest \\
\hline 0 & Low representativeness and without pedagogical interest \\
\hline 0.33 & With some representativeness but with low pedagogical interest \\
\hline 0.67 & Good example of processes but hard to explain to non experts \\
\hline 1.00 & Good example of processes and/or good pedagogical resource \\
\hline Dv & Number of interesting geomorphological features (diversity) \\
\hline 0 & 1 \\
\hline 0.33 & 2 \\
\hline 0.67 & 3 \\
\hline 1.00 & More than 3 \\
\hline Ge & Other geological features with heritage value \\
\hline 0 & Absence of other geological features \\
\hline 0.17 & Other geological features but without relation to geomorphology \\
\hline 0.33 & Other geological features with relation to geomorphology \\
\hline 0.50 & Occurrence of other geosite(s) \\
\hline Kn & Scientific knowledge on geomorphological issues \\
\hline 0 & None \\
\hline 0.25 & Medium: presentations, national papers \\
\hline 0.50 & High: international papers, thesis \\
\hline $\mathbf{R n}$ & Rareness at national level \\
\hline 0 & More than 5 occurrences \\
\hline 0.17 & Between 3 to 5 occurrences \\
\hline 0.33 & 2 occurrences \\
\hline 0.50 & The only occurrence \\
\hline ScV & Scientific value (Ra + In + Rp + Dv + Ge + Kn + Rn) \\
\hline & \\
\hline
\end{tabular}

Tab. 2: Numerical assessment of the geomorphosite indicator «scientific value» Quantitative Bewertung des Wissenschaftichen Werts der geomorphologischen Geotope Evaluation numérique de la valeur scientifique des géomorphosites

results. Thus, geomorphosites that score well over the full spectrum of indicators will also be amongst the best placed in final ranking. Final ranking is consequently felt to be particular useful for supporting site management decisions with regards prioritisation of measures for the protection, education (e.g. setting up trails, installation of descriptive panels) and promotion of geomorphosites.

\section{Results}

Of 154 potential sites, 26 were selected for further assessment. These sites formed the basis of the inventory of geomorphological heritage of the Montesinho Natural Park (Fig. 1). They included 17 «panoramic viewpoints», 7 «areas» and 2 «single places» (definition given above). Whereas the areas are predominantly 


\begin{tabular}{|c|c|c|}
\hline \multicolumn{3}{|c|}{ G. ADDitional VAlues (AdV) (maximum 4.5) } \\
\hline Cult & \multicolumn{2}{|c|}{ Cultural value } \\
\hline 0 & \multicolumn{2}{|c|}{ Without cultural features or with cultural features damaging the site } \\
\hline 0.25 & \multicolumn{2}{|c|}{ Cultural features with no connection to landforms } \\
\hline 0.50 & \multicolumn{2}{|c|}{ Relevant cultural features with no connection to landforms } \\
\hline 0.75 & \multicolumn{2}{|c|}{ Immaterial cultural features related to landforms } \\
\hline 1.00 & \multicolumn{2}{|c|}{ Material cultural features related to landforms } \\
\hline 1.25 & \multicolumn{2}{|c|}{ Relevant material cultural features related to landforms } \\
\hline 1.50 & \multicolumn{2}{|c|}{ Anthropic landform with high cultural relevance } \\
\hline Aest & \multicolumn{2}{|c|}{ Aesthetic value } \\
\hline $0-0.5$ & Low & \multirow{3}{*}{$\begin{array}{l}\text { Subjective value. Aspects to be considered: visual singularity of landforms; } \\
\text { panoramic quality; objects and colour diversity and combination; presence of } \\
\text { water and vegetation; absence of human-induced deterioration; proximity to } \\
\text { the observed features. }\end{array}$} \\
\hline $0.5-1$ & Medium & \\
\hline $1-1.5$ & High & \\
\hline Ecol & \multicolumn{2}{|c|}{ Ecological value } \\
\hline 0 & \multicolumn{2}{|c|}{ Without relation to biological features } \\
\hline 0.38 & \multicolumn{2}{|c|}{ Occurrence of interesting fauna and/or flora } \\
\hline 0.75 & \multicolumn{2}{|c|}{ One of the best places to observe interesting fauna and/or flora } \\
\hline 1.12 & \multicolumn{2}{|c|}{ Geomorphological features are important for ecosystem(s) } \\
\hline 1.50 & \multicolumn{2}{|c|}{ Geomorphological features are crucial for the ecosystem(s) } \\
\hline AdV & \multicolumn{2}{|c|}{ Additional values (Cult + Aest + Ecol) } \\
\hline
\end{tabular}

Tab. 3: Numerical assessment of the geomorphosite indicator «additional values» Quantitative Bewertung der Zusatzwerte der geomorphologischen Geotope Evaluation numérique des valeurs additionnelles des géomorphosites

characterised by granite landforms (Fig. 2), the single places are all landforms with high «cultural value» (Fig. 3). The large number of panoramic viewpoints reflects a touch of pragmatism, as from these points a great variety of landforms may be observed. It appears that the main landforms in this particular park are mostly tectonic or residual in character (Pereira et al. 2003).

The results of the numerical assessment and ranking of geomorphosites are presented in Tab. 6. L08 (Santa Ana) appears to be the most valuable geomorphosite in MNP, scoring highest in total value and final ranking, despite coming fifth in «geomorphological value» and second in «management value». L05, L08, L21 and L11 are strongest in terms of «management value», and also scored highest in total value and final ranking. Of these sites, total value and final ranking are only slightly different between L21 and L05. Whereas L05 has a higher total value $(14,84 /$ second highest $)$ due to its high score in «management value» (8,76/highest) and despite a medium score in «geomorphological value» $(6,08$ ) eleventh position), L21 has a better final ranking (36/ second) because of a higher ranking over all indicators. L17 has a high «geomorphological value» (7,12/fourth position) because of its significant «cultural value» but it also has the lowest score in «management value» $(4,28)$ due to its extreme vulnerability.

The quantification stage supported the selection of 13 geomorphosites for promotion, in particular for their inclusion in a guidebook on the geological heritage of the park. The selection was influenced predominantly by the results of the final ranking, but it did take into account the results of individual indicators.

\section{Discussion}

The focus of this paper is on the process involved in the selection and description of geomorphosites. The proposed methodological framework involves two main stages and a total of six sub-stages. The approach aims to take both qualitative and quantitative aspects into account to allow for a holistic and detailed assessment of geomorphosites (PanizZa 2001).

During the last decade and, in particular, since the creation of the Geomorphosites Working Group of the International Association of Geomorphologists in 2001 (CoRATZa \& ReynaRD 2005), much has been 


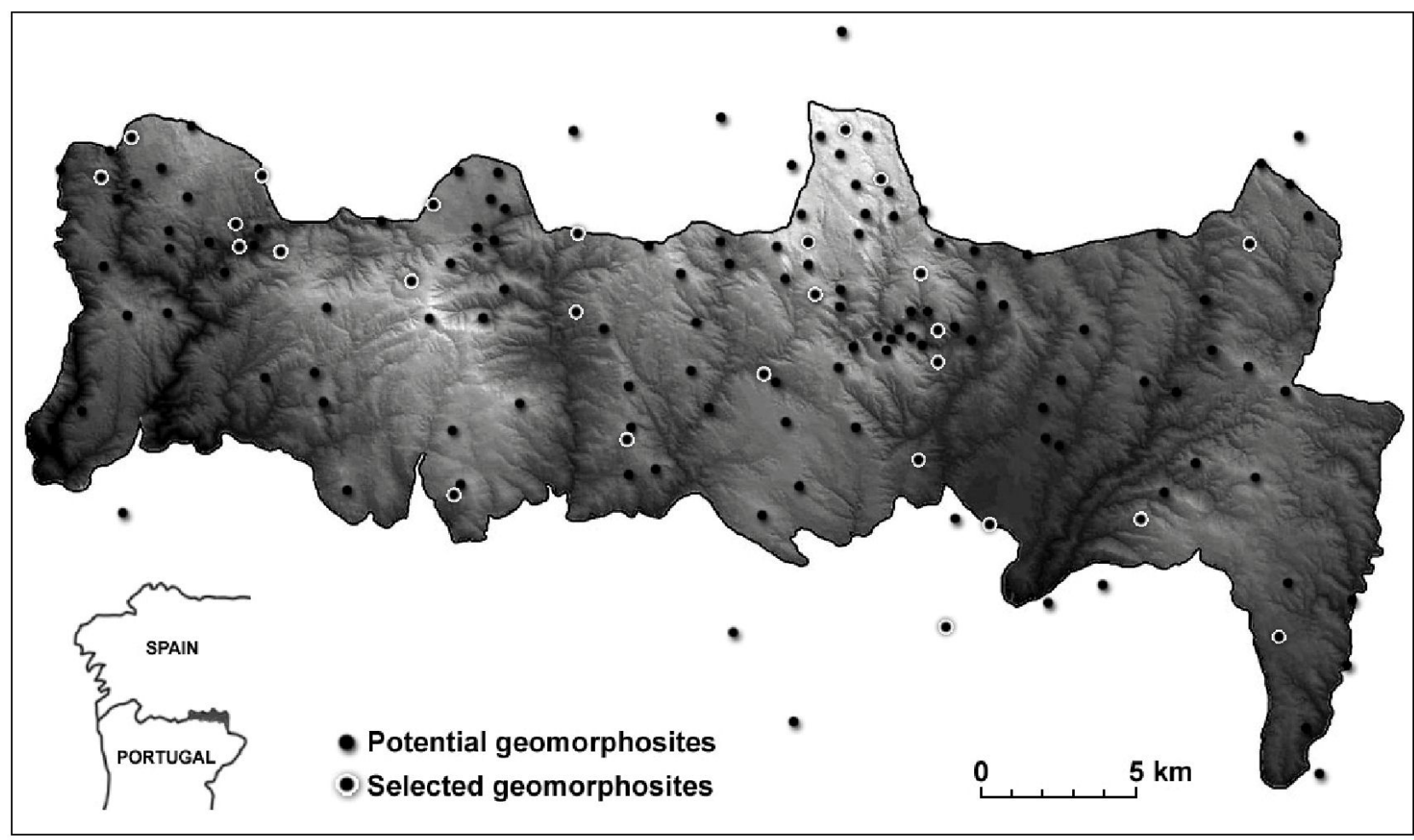

Fig. 1: Location of inventorised geomorphosites in the Montesinho Natural Park Geographische Lage der bewerteten geomorphologischen Geotope des Naturparks von Montesinho Situation des géomorphosites inventoriés dans le Parc naturel de Montesinho

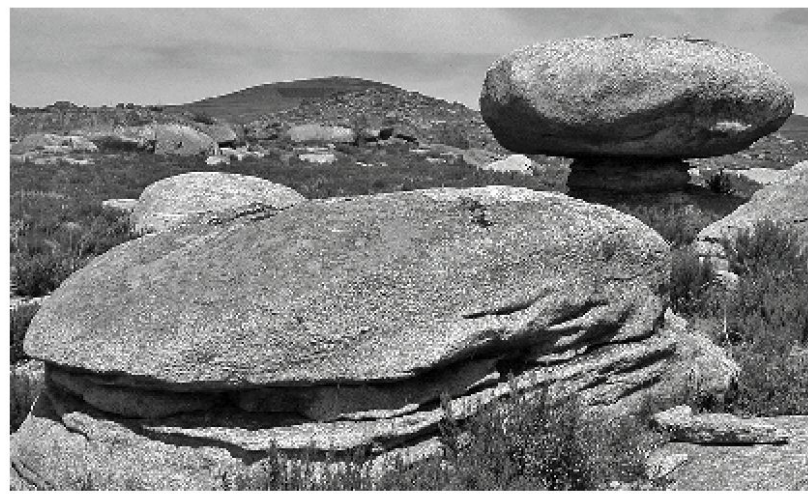

Fig. 2: Cheira da Noiva geomorphosite (L13), an example of a granite area with significant «aesthetic value»

Geomorphologisches Geotop Cheira da Noiva (L13), ein Beispiel einer Granit-Region mit signifikantem Ästhetischen Wert

Géomorphosite Cheira da Noiva (L13), un exemple de site granitique ayant une valeur esthétique significative

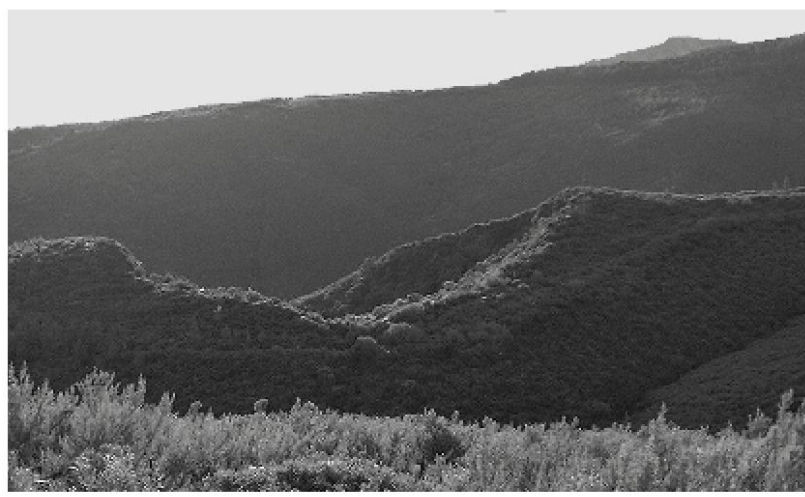

Fig. 3: Boca da Caborca geomorphosite (L07), a landform with «cultural value» as a result of the Roman gold mining

Geomorphologisches Geotop Boca da Caborca (L07), eine Landschaftsform mit hohem Kulturellen Wert aufgrund des Goldabbaus zur Zeit der Römer

Géomorphosite Boca da Caborca (L07), une forme du relief à haute valeur culturelle en raison de la présence de l'exploitation d'une mine d'or à l'époque romaine 


\begin{tabular}{|l|l|}
\hline \multicolumn{2}{|l|}{ H. USE VALUE (UsV) (maximum 7.0) } \\
\hline Ac & Accessibility \\
\hline 0 & Very difficult, only with special equipment \\
\hline 0.21 & Only by 4 wheel-drive vehicle and more than 500 metres by footpath \\
\hline 0.43 & By car and more than 500 metres by footpath \\
\hline 0.64 & By car and less than 500 metres by footpath \\
\hline 0.86 & By 4 wheel-drive vehicle and less than 100 metres by footpath \\
\hline 1.07 & By car and less than 50 metres by footpath \\
\hline 1.29 & By bus on local roads and less than 50 metres by footpath \\
\hline 1.50 & By bus on national roads and less than 50 metres by footpath \\
\hline Vi & Visibility \\
\hline 0 & Very difficult or not visible at all \\
\hline 0.30 & Can only be viewed using special equipment (e.g. artificial light, ropes) \\
\hline 0.60 & Limited by trees or lower vegetation \\
\hline 0.90 & Good but need to move around for a complete observation \\
\hline 1.20 & Good for all relevant geomorphological features \\
\hline 1.50 & Excellent for all relevant geomorphological features \\
\hline Gu & Present use of the geomorphological interest \\
\hline 0 & Without promotion and not being used \\
\hline 0.33 & Without promotion but being used \\
\hline 0.67 & Promoted/used as landscape site \\
\hline 1.00 & Promoted/used as geomorphosite or geosite \\
\hline Ou & Present use of other natural and cultural interests \\
\hline 0 & Without other interests, promotion and use \\
\hline 0.33 & With other interests but without promotion and use \\
\hline 0.67 & With other interests and their promotion, but without other use \\
\hline 1.00 & With other interests, with promotion and use \\
\hline Lp & Legal protection and use limitations \\
\hline 0 & With total protection and prohibitive use \\
\hline 0.33 & With protection, with use restriction \\
\hline 0.67 & Without protection and without use restriction \\
\hline 1.00 & With protection but without use restriction or with very low use restriction \\
\hline $\mathbf{E q}$ & Equipment and support services \\
\hline 0 & Hostelry and support services are more than $25 \mathrm{~km}$ away \\
\hline 0.25 & Hostelry and support services are between 10 and $25 \mathrm{~km}$ away \\
\hline 0.50 & Hostelry and support services are between 5 and 10 km away \\
\hline 0.75 & Hostelry or support services are less than $5 \mathrm{~km}$ away \\
\hline 1.00 & Hostelry and support services are less than $5 \mathrm{~km} \mathrm{away}$ \\
\hline UsV & Use value (Ac+Vi+Gu+Ou+Lp+Eq) \\
\hline
\end{tabular}

Tab. 4: Numerical assessment of the geomorphosite indicator «use value» Quantitative Bewertung des Nutzungswerts der geomorphologischen Geotope Evaluation numérique de la valeur d'usage des géomorphosites

written about geomorphosite assessment using quantitative methods (BONACHEA et al. 2005; BRUSCHI \& Cendrero 2005; Coratza \& Giusti 2005; GrandgiRard 1997; PANizza 2001; Pralong 2005; Restrepo 2004; Rivas et al. 1997; SERrano \& GonzÁlez-Trueba 2005). However, although emphasis has been given in these publications to numerical assessment in view of increasing objectivity of results, the more subjective and often unsystematic process of selection of landforms to be assessed does not seem to have received its due attention.

It is argued herein that an element of subjectivity is present at all stages of an assessment and,in particular, 


\begin{tabular}{|l|l|}
\hline \multicolumn{2}{|l|}{ I. PROTECTION VALUE (VPR) (maximum 3.0) } \\
\hline In & Integrity/Intactness \\
\hline 0 & Highly damaged as a result of human activities \\
\hline 0.25 & Damaged as a result of natural processes \\
\hline 0.50 & Damaged but preserving essential geomorphological features \\
\hline 0.75 & Slightly damaged but still maintaining the essential geomorphological features \\
\hline 1.00 & No visible damage \\
\hline $\mathbf{V u}$ & Vulnerability of use as geomorphosite \\
\hline 0 & Very vulnerable, with possibility of total loss \\
\hline 0.50 & Geomorphological features may be damaged \\
\hline 1.00 & Other, non-geomorphological features may be damaged \\
\hline 1.50 & Damage can occur only in/along the access structures \\
\hline 2.00 & Not vulnerable \\
\hline PrV & Protection value (In + Vu) \\
\hline
\end{tabular}

Tab. 5: Numerical assessment of the geomorphosite indicator «protection value». The criterion of integrity (In) is included in «scientific value» and «protection value» because of its relevance for both.

Quantitative Bewertung des Schutzwerts der geomorphologischen Geotope. Das Kriterium des Erhaltungszustandes (In) wird beim Wissenschaftlichen Wert und beim Schutzwert berücksichtigt, da es für beide Indikatoren von Bedeutung ist.

Evaluation numérique de la valeur de protection des géomorphosites. Le critère Intégrité (In) apparaît dans la valeur scientifique et dans la valeur de protection parce qu'il constitue un indicateur pertinent pour les deux valeurs.

during the selection phase of inventory compilation. Even during the quantification stage it would seem impossible to avoid subjectivity, as the allocation of values for most criteria again depends on the opinion of the assessor. This is all the more relevant if note is taken that numerical assessment is propagated as a means of reducing subjectivity in order to increase objectivity of geomorphosite comparison and general assessment.

The presented approach, further, would seem to put greater demands on the expertise of the assessor by including scientific and non-scientific criteria (such as «additional values», potential use and management) for judgement.

Most of the criteria proposed for the numerical assessment were taken from existing literature on the field. Criteria considered most relevant for an assessment method focussing specifically on geomorphosites were chosen and divided amongst the four main types of indicators: «scientific value», «additional values», «use value» and «protection value». Thus, for «scientific value» (Tab. 2), rareness, integrity/intactness, representativeness and diversity were selected. Criteria, like size and age, although often included in other approaches to assessment, were not considered here on the grounds that they are not seen to be significant fea- tures of geomorphology. For «additional values» (Tab. 3), cultural, aesthetic and ecological aspects were taken into consideration. Accessibility and visibility were felt to be the most relevant criteria for «use value» of geomorphosites (Tab. 4) as they clearly reflect economic/ tourism needs. For the final indicator, present levels of deterioration and expected damage due to geomorphosite use were taken into account (Tab. 5).

The results of the Montesinho Natural Park geomorphosite assessment show that sites with highest «scientific value» are not automatically overall bestranked, revealing the importance of careful weighting of factors. In this approach, management and scientific aspects were given equal weighting.

\section{Conclusion}

Traditionally, the distinction between the selection of geomorphosites and their quantitative assessment is not well defined. The geomorphosite assessment designed for the Montesinho Natural Park takes this into account, proposing a clear distinction between both stages, that is between the compilation of an inventory and its evaluation, yet still ensuring incorporation of results from both stages into the final results. Although it is emphasised that a complete assessment 


\begin{tabular}{|c|c|c|c|c|c|c|c|c|}
\hline Rank & $\begin{array}{c}\text { Scientific } \\
\text { Value } \\
(\mathbf{S c V})\end{array}$ & $\begin{array}{l}\text { Add. } \\
\text { Values } \\
\text { (AdV) }\end{array}$ & $\begin{array}{c}\text { Geom. } \\
\text { Value } \\
(\mathrm{GmV})\end{array}$ & $\begin{array}{c}\text { Use } \\
\text { Value } \\
\text { (UsV) }\end{array}$ & $\begin{array}{c}\text { Protect. } \\
\text { Value } \\
\text { (PrV) }\end{array}$ & $\begin{array}{l}\text { Manag. } \\
\text { Value } \\
(\mathrm{MnV})\end{array}$ & $\begin{array}{l}\text { Total } \\
\text { Value } \\
\text { (TtV) }\end{array}$ & $\begin{array}{c}\text { Final } \\
\text { Ranking } \\
\text { (Rk) }\end{array}$ \\
\hline $\mathbf{1}$ & L06 (5.00) & L07 (3.62) & L09 (7.58) & $\mathbf{L 0 5}(6.01)$ & L08 (3.00) & L05 (8.76) & L08 (15.37) & L08 (23) \\
\hline 2 & $\mathbf{L 0 9}(4.83)$ & L17 (3.37) & $\mathbf{L 0 3}(7.41)$ & L08 (5.33) & L21 (3.00) & L08 (8.33) & L05 (14.84) & L21 (36) \\
\hline 3 & $\mathbf{L 0 3}(4.41)$ & $\mathbf{L 1 3}(3.37)$ & L06 (7.38) & L21 (4.95) & L12 (3.00) & L21 (7.95) & L21 (14.56) & $\mathbf{L 0 5}(45)$ \\
\hline 4 & L08 (4.41) & L11 (3.12) & $\mathbf{L 1 7}(7.12)$ & L11 (4.89) & $\mathbf{L 2 6}(3.00)$ & $\operatorname{L11}(7.64)$ & L11 (14.18) & L11 (45) \\
\hline 5 & L05 (4.08) & L10 (3.12) & L08 (7.04) & $\mathbf{L 1 0}(4.56)$ & L05 (2.75) & L15 (6.81) & L06 (13.85) & L06 (48) \\
\hline 6 & L04 (4.08) & $\mathbf{L 0 3}(3.00)$ & $\mathbf{L 1 3}(7.03)$ & L16 (4.41) & L11 (2.75) & L16 (6.66) & L09 (13.84) & L09 (51) \\
\hline 7 & L21 (3.99) & $\mathbf{L 0 9}(2.75)$ & $\mathbf{L 0 7}(6.78)$ & $\mathbf{L 1 5}(4.31)$ & L22 (2.75) & $\mathbf{L 1 2}(6.51)$ & $\mathbf{L 0 3}(13.26)$ & $\mathbf{L 0 3}(66)$ \\
\hline 8 & L01 (3.91) & L08 (2.63) & $\mathbf{L 2 1}(6.61)$ & $\mathbf{L 0 6}(4.22)$ & $\mathbf{L 1 5}(2.50)$ & L06 (6.47) & $\mathbf{L 1 3}(12.92)$ & $\mathbf{L 1 3}(71)$ \\
\hline 9 & L17 (3.75) & $\mathbf{L 2 0}(2.63)$ & $\mathbf{L 1 1}(6.54)$ & L20 (4.07) & L04 (2.50) & L26 (6.39) & $\mathbf{L 1 2}(12.30)$ & L12 (83) \\
\hline 10 & L24 (3.74) & $\mathbf{L 2 1}(2.62)$ & L24 (6.11) & $\mathbf{L 0 9}(4.01)$ & $\mathbf{L 0 3}(2.50)$ & L20 (6.32) & L07 (12.21) & L20 (88) \\
\hline 11 & L26 (3.67) & L06 (2.38) & $\mathbf{L 0 5}(6.08)$ & $\mathbf{L 1 3}(3.89)$ & L16 (2.25) & $\mathbf{L 0 9}(6.26)$ & L10 (12.09) & L07 (89) \\
\hline 12 & L13 (3.66) & $\mathbf{L 2 3}(2.38)$ & $\mathbf{L 1 0}(6.03)$ & L18 (3.88) & L06 (2.25) & L04 (6.10) & $\mathbf{L 2 0}(11.95)$ & L15 (91) \\
\hline 13 & $\mathbf{L 2 3}(3.58)$ & L12 (2.38) & $\mathbf{L 2 3}(5.96)$ & $\mathbf{L 1 7}(3.78)$ & $\mathbf{L 2 0}(2.25)$ & L10 (6.06) & L04 (11.93) & L10 (91) \\
\hline 14 & L11 (3.42) & L18 (2.38) & L04 (5.83) & L01 (3.75) & L09 (2.25) & L01 (6.00) & L15 (11.93) & L04 (95) \\
\hline 15 & L02 (3.42) & $\mathbf{L 2 4}(2.37)$ & L12 (5.79) & $\mathbf{L 1 4}(3.72)$ & L01 (2.25) & L13 (5.89) & L01 (11.79) & L17 (96) \\
\hline 16 & L12 (3.41) & L15 (2.13) & L01 (5.79) & L07 (3.68) & $\mathbf{L 1 3}(2.00)$ & L03 (5.77) & L24 (11.75) & L24 (102) \\
\hline 17 & L07 (3.16) & L14 (2.13) & L20 (5.63) & L24 (3.64) & L24 (2.00) & L24 (5.64) & L26 (11.44) & L01 (103) \\
\hline 18 & $\mathbf{L 2 0}(3.00)$ & L19 (2.13) & L18 (5.38) & L04 (3.60) & L02 (2.00) & L18 (5.63) & $\mathbf{L 1 7}(11.40)$ & L26 (108) \\
\hline 19 & L18 (3.00) & $\mathbf{L 2 5}(2.13)$ & L02 (5.30) & $\mathbf{L 0 2}(3.55)$ & $\mathbf{L 2 5}(2.00)$ & L02 (5.55) & L16 (11.29) & L16 (110) \\
\hline 20 & L16 (3.00) & $\mathbf{L 0 5}(2.00)$ & L15 (5.12) & $\mathbf{L 1 2}(3.51)$ & L18 (1.75) & L07 (5.43) & L18 (11.01) & L18 (121) \\
\hline 21 & L15 (2.99) & L01 (1.88) & L26 (5.05) & L26 (3.39) & L07 (1.75) & L22 (5.42) & L02 (10.85) & L02 (133) \\
\hline 22 & L10 (2.91) & L02 (1.88) & L14 (4.87) & $\mathbf{L 0 3}(3.27)$ & L19 (1.75) & L14 (5.22) & $\mathbf{L 2 3}(10.50)$ & $\mathbf{L 2 3}(135)$ \\
\hline 23 & L22 (2.91) & L04 (1.75) & $\mathbf{L 1 9}(4.79)$ & $\mathbf{L 1 9}(3.10)$ & $\mathbf{L 1 0}(1.50)$ & L25 (5.09) & L14 (10.09) & L14 (147) \\
\hline 24 & L14 (2.74) & L16 (1.63) & L16 (4.63) & L25 (3.09) & L14 (1.50) & L19 (4.85) & $\mathbf{L 2 2}(9.71)$ & L22 (153) \\
\hline 25 & $\mathbf{L 1 9}(2.66)$ & $\mathbf{L 2 6}(1.38)$ & $\mathbf{L 2 5}(4.46)$ & $\mathbf{L 2 3}(3.04)$ & $\mathbf{L 2 3}(1.50)$ & $\mathbf{L 2 3}(4.54)$ & L19 $(9.64)$ & $\mathbf{L 1 9}(160)$ \\
\hline 26 & $\mathbf{L 2 5}(2.33)$ & $\mathbf{I 2 2}(1.38)$ & L22 (4.29) & $\mathbf{L 2 2}(2.67)$ & $\mathbf{L 1 7}(0.50)$ & L17 (4.28) & $\mathbf{L 2 5}(9.55)$ & L25 (162) \\
\hline
\end{tabular}

Tab. 6: Results of geomorphosite numerical assessment in Montesinho Natural Park

Resultate der quantitativen Bewertung der geomorphologischen Geotope des Naturparks von Montesinho Résultats de l'évaluation numérique des géomorphosites du Parc naturel de Montesinho

should include both stages, to ensure flexibility in use, the methodology does make allowance for use of only part of the proposed method, where appropriate. Thus, numerical assessment of geomorphosites that were inventoried at an earlier period in time is possible. Equally, potential geomorphosites can be assessed directly using the quantitative stage.

Use of this assessment approach allows all data collected from the initial qualitative assessment to the final quantification to flow into the final results. It allows reduction of subjectivity, particularly in the quantitative stage. It can be applied to other protected areas and other types of areas as well, independent of their size.

It is argued here, in particular, not only for the combination of quantitative and qualitative evaluation procedures, but for equal weighting of management and scientific aspects and factors. The approach implemented for the assessment of the Montesinho Natural
Park, for example, would have been equally effective for definition of sites with either greatest «geomorphological value» or with best tourist potential

\section{References}

Bonachea, J., Bruschi, V., Remondo, J., GonzálezDíez, A., Salas, L., Bertens, J., Cendrero, A., Otero, C., Giusti, C., Fabbri, A., González-Lastra, J. \& J. ARAMBURU (2005): An approach for quantifying geomorphological impacts for EIA of transportation infrastructures: a case study in northern Spain. - In: Geomorphology 66: 95-117.

Brilha, J. (2005): Património geológico e geoconservação. A conservação da natureza na sua vertente geológica. - Viseu: Palimage.

Bruschi, V. \& A. Cendrero (2005): Geosite evaluation: can we measure intangible values? - In: Piacente, S. \& P. Coratza (eds): Geomorphological sites and geodiversity. - In: Il Quaternario 18, 1:293-306. 
Coratza, P. \& C. Giusti (2005): Methodological proposal for the assessment of the scientific quality of geomorphosites. - In: Piacente, S. \& P. CoRatza (eds): Geomorphological sites and geodiversity. - In: Il Quaternario 18, 1: 307-313.

Coratza, P. \& E. Reynard (2005): Assessing, mapping and protecting geomorphosites: a working group of the International Association of Geomorphologists (IAG). - In: EArth Sciences Centre (ed.): Abstracts of the IV International Symposium ProGEO on the Conservation of the Geological Heritage, Braga, 11-13 September 2005: 9.

GRANDGIRARD, V. (1997): Géomorphologie, protection de la nature et gestion du paysage. - Thèse de doctorat, Institut de Géographie, Université de Fribourg.

GrandGiRARD, V. (1999): L'évaluation des géotopes. - In: Geologia Insubrica 4, 1: 59-66.

Panizza, M. (2001): Geomorphosites. Concepts, methods and examples of geomorphological survey. - In: Chinese Science Bulletin 46: 4-6.

Panizza, M. \& S. Piacente (1993): Geomorphological assets evaluation. - In: Zeitschrift für Geomorphologie, Supplementband 87:13-18.

Pereira, D.I., Pereira, P., Caetano Alves, M.I. \& J. BRILHA (2006): Inventariação temática do património geomorfológico português. - In: Publicações da Associação Portuguesa de Geomorfólogos 3: 155-160.

Pereira, P., Pereira, D.I., Caetano Alves, M.I. \& C. Meireles (2003): Geomorfologia do Parque Natural de Montesinho: controlo estrutural e superfícies de aplanamento. - In: Ciências da terra (UNL), vol. esp. V: C61-C64.

Pereira, P. (2006): Património geomorfológico: conceptualização, avaliação e divulgação. Aplicação ao Parque Natural de Montesinho. - PhD thesis, Earth Sciences Department, University of Minho.

Pralong, J.P. (2005): A method for assessing tourist potential and use of geomorphological sites. - In: Géomorphologie: relief, processus, environnement 3: 189-196.

Restrepo, C. (2004): Patrimonio geomorfológico de la región central antioqueña (Colombia). - In: MATAPerellò, J. (ed.): Actas del Congreso Internacional sobre Patrimonio Geológico y Minero (Defensa del Património y Desarrollo Regional), Utrillas, 25 28 September 2003. - Madrid: Sociedad Española para la Defensa del Patrimonio Geológico y Minero (SEDPGYM): 211-219.

REYNARD, E. (2005): Geomorphosites et paysages. - In: Géomorphologie: relief, processus, environnement 3: 181-188.

Rivas, V., Rix, K., Frances, E., Cendrero, A. \& D. Brunsden (1997): Geomorphological indicators for environmental impact assessment: consumable and non-consumable geomorphological resources. - In: Geomorphology 18: 169-182.

Serrano, E. \& J. González-Trueba (2005): Assess- ment of geomorphosites in natural protected areas: the Picos de Europa National Park (Spain). - In: Géomorphologie: relief, processus, environnement 3: 197-208. WATSON,E. \& O.SLAYMAKER (1966): Mid-Wales, a survey of geomorphological sites. - Aberystwyth: Department of Geography, University College of Wales.

\section{Summary: Geomorphosite assessment in Montesinho Natural Park (Portugal)}

The Montesinho Natural Park (MNP), with an area of about $750 \mathrm{~km}^{2}$, is one of the largest protected areas in Portugal. Since its inauguration as a natural park in 1979, geological and geomorphological aspects have not been taken into consideration in its nature conservation policies. Over the last few years, this deficit has been compensated with an assessment of its geomorphological heritage. The assessment was made possible due to a research project on the geological heritage of the natural parks of north-eastern Portugal. The assessment method propagated herein proposes a clear definition of three types of geomorphosites: single places, geomorphological areas or panoramic viewpoints. Further, it proposes as two-staged approach to assessment with inventory compilation followed by quantification of value. Inventory compilation, for example, involves the identification and qualitative assessment of potential geomorphosites and, therefore, the selection and characterization of geomorphosites. The quantification stage includes the numerical assessment of sites and their final ranking. The values are numerically assessed using selected criteria. The implementation of this approach in the MNP led to the identification of 154 potential geomorphosites, of which only 26 were selected after the qualitative assessment or characterisation process. The numerical assessment of the sites and their ranking allowed a final selection of 13 sites for public use.

\section{Zusammenfassung: Bewertung der geomorpholo- gischen Geotope des Naturparks von Montesinho (Portugal)}

Der Naturpark von Montesinho (PNM) ist mit einer Fläche von ca. $750 \mathrm{~km}^{2}$ eines der grössten Schutzgebiete Portugals. Auch wenn der Park 1979 gegründet wurde, sind die Geologie und die Geomorphologie bisher nicht in die Politik des Umwelt- und Naturschutzes des Parks integriert. Während der letzten Jahre wurde das geomorphologische Erbe des PNM jedoch im Rahmen eines Forschungsprojektes betreffend des geologischen Erbes der Naturparks in Nordostportugal bewertet. Die hier vorgestellte Methode unterscheidet zwischen drei Arten von geomorphologischen Geotopen und ist in zwei Bewertungsphasen unterteilt. Die geomorphologischen Geotope sind demnach Einzelobjekte, geomorphologische Flächen oder Aussichtspanoramen. Die zwei Hauptphasen 
entsprechen dem Inventar und der Quantifizierung. Die Inventarphase beinhaltet die Identifikation, die qualitative Bewertung der potentiellen geomorphologischen Geotope, die Selektion und die Charakterisierung der Objekte. Die Quantifizierungsphase verläuft in zwei Etappen: die quantitative Bewertung - basierend auf verschiedenen Kriterien - und das Ranking. Die geomorphologische Studie des PNM erlaubte, 154 potentielle geomorphologische Geotope zu identifizieren. Nach der qualitativen Bewertung wurden 26 Objekte ausgeschieden und als geomorphologische Geotope anerkannt. Aufgrund der quantitativen Bewertung und des Rankings wurden schlussendlich 13 Objekte für eine öffentliche Nutzung ausgewählt.

\section{Résumé: Evaluation des géomorphosites du Parc naturel de Montesinho (Portugal)}

Le Parc naturel de Montesinho (PNM) constitue l'une des plus grandes zones protégées du Portugal, avec une surface d'environ $750 \mathrm{~km}^{2}$. Bien que le Parc ait été créé en 1979, la géologie et la géomorphologie n'ont pas encore été intégrées dans la politique de protection de la nature. Au cours des dernières années, le patrimoine géomorphologique du PNM a toutefois été évalué dans le cadre d'un projet de recherche portant sur le patrimoine géologique des parcs naturels du nord-est du Portugal. La méthode d'évaluation proposée, qui distingue trois types de géomorphosites, est divisée en deux principales phases d'évaluation correspondant à l'inventaire et à la quantification. La phase d'inven- taire comporte l'identification, l'évaluation qualitative des géomorphosites potentiels, leur sélection et leur caractérisation. La phase de quantification comporte deux étapes: l'évaluation numérique - sur la base d'un certain nombre de critères - et le classement. L'étude géomorphologique du PNM a permis d'identifier 154 géomorphosites potentiels. Suite à l'évaluation qualitative, seuls 26 sites ont été sélectionnés et considérés comme des géomorphosites. L'évaluation numérique et le classement des sites ont permis de sélectionner finalement 13 sites propices à une utilisation publique.

Dr. Paulo Pereira, Prof. Dr. Diamantino Pereira, Prof. Dr. Maria Isabel Caetano Alves, Earth Sciences Centre, Campus de Gualtar, University of Minho, 4710-057 Braga, Portugal.

e-mail:

paolo@dct.uminho.pt

insuad@dct.uminho.pt

icaetano@dct.uminho.pt

Manuskripteingang/received/manuscrit entré le 21.1.2007

Annahme zum Druck/accepted for publication/accepté pour limpression: 27.9.2007 